\title{
Transcriptome, Biochemical and Growth Responses of the Marine Phytoplankter Phaeodactylum Tricornutum Bohlin (Bacillariophyta) to Copepod Grazer Presence
}

\author{
Si Lia,b Stefanie M.H. Ismar ${ }^{b}$ \\ aHebei University of Technology, School of Marine Science and Engineering, Tianjin, China, 'bEOMAR \\ Helmholtz Center for Ocean Research Kiel, Experimental Ecology - Food Webs, Kiel, Germany
}

\section{Key Words}

Essential nutrient content $\bullet$ Grazing stress $\bullet$ Phaeodactylum tricornutum $\bullet$ Marine phytoplankton - RNA sequencing • Transcriptome.

\begin{abstract}
Background/Aims: As a model organism for a pleiomorphic marine planktonic primary producer, Phaeodactylum tricornutum has been studied on a molecular level under diverse cultural conditions. But little is known about its morphological, nutritional or transcriptomic responses under grazing stress. Methods: To assess microalgal molecular and cellular responses to grazer presence, we conducted transcriptome profiling in combination with growth rate, biovolume, fatty acid content, carbon and nitrogen content measurements in the model diatom Phaeodactylum tricornutum. RNA-sequencing was used to evaluate the transcriptomic response to grazing stress for P. tricornutum strain CCAP 1055/1. Results: Among the differentially expressed genes, we found down-regulation of genes involved in pathogen resistance, and in fatty acid biosynthesis pathways, while mitosis-involved genes were up-regulated. Experimentally testing morphological and biochemical responses in five strains of the species, we detected strain-specific significant effects of simulated grazing pressure in altered growth rates, biovolume and nutritional composition. Conclusion: Our research reveals the associated molecular and cellular responses to grazing effects in $P$. tricornutum and extends the understanding of co-evolutionary roles in regulating grazing defence between $P$. tricornutum and its grazer.

\section{Introduction}

Marine phytoplankton contribute nearly half the global primary productivity [1], and among them, diatoms provide the most important basis of marine food webs, nourishing 
higher trophic levels with biomass and essential nutrients [2]. Decline of phytoplankton concentration due to global warming was observed at a rate of $\sim 1 \%$ of the global median per year [3]; yet, grazing effects can overrule impacts of increasing temperatures and other environmental factors such as nutrient availabilities [4, 5], which makes understanding the processes of phytoplankton performance under grazing more crucial than ever.

The diatom Phaeodactylum tricornutum possesses a suite of unique properties, which make it a well-suited model organism for studies of algal physiological, biochemical and molecular traits: 1 , P. tricornutum exhibits polymorphic interconversion [6], which can be triggered by environmental changes [7]. 2, P. tricornutum grows rapidly to high cell densities, biomass and lipid content [8] (20\% of dry weight, even more under nutrient depletion) [9]. 3 , P. tricornutum owns a distinct genetic background and possesses a relatively small genome [10]. To understand more about the biology of diatoms and their ecological roles in aquatic environments, previous research on $P$. tricornutum has uncovered its systematic responses to environmental stress - they are sophisticated in detecting and adapting to various biotic and abiotic stress factors and contain several signaling pathways that exist in both plants and animals [11-13]. But few studies to-date have focused on this species' responses to grazing stress.

Marine diatoms and copepods are ubiquitous and globally important primary producers and consumers in marine food webs [14]. Over the years, studies on the signal transfer between diatoms and their grazers have been conducted, investigating a range of operative pathways from mechanical to chemical perception on both sides, predator and prey $[15,16]$.

Copepod feeding responses to algal chemistry. Until the 1970s, with a few exceptions [17], ingestion in copepods was considered a non-selective process and a random grazing behavior which mechanically responded to size and availability of preys [18]. Thereafter, a body of evidence regarding grazing selection by copepods gradually built up, mostly involving mechanical and chemical perception of food particles before digestion of the food [19]. Poulet and Marsot's early experiments using artificial packaged foods which contained chemical signals to feed calanoid copepods [20] showed the importance of chemical induction for copepod grazing. Subsequently, a series of studies on chemical perception involving toxin detection, as well as the evaluation of food quality of particles started [21, 22]. Huntley et al [21]., for example, recorded that the chemical signals produced by the dinoflagellates can induce food particle rejection in Calanus pacificus. Copepod grazing can be reduced where grazers are exposed to toxins [21-23]. If there are alternative sources of food, copepods actively avoided toxic food [24]. Copepods display differential feeding activity, when encountering distinct levels of toxins [25]. Besides changing the grazing behavior according to altered toxin levels, copepods can select food based on its nutritional quality $[15,26]$. Conversely, the morphological [27], chemical, and life history of diatoms can change [28] as a response to cues from grazers - such as mechanical damage, herbivore-released chemicals and specific chemical compounds that are feeding-related. Thus, diatoms have the potential to significantly influence their consumers, and cause cascading impacts via their altered edibility, palatability or toxiticity on entire plankton food webs and affected marine ecosystems [29].

Since various stress factors, nutrient sources, and toxins which significantly differ in biochemical composition may affect copepod grazing [16, 25, 30,31], study beyond species level in an otherwise well-described model system may unravel a deeper understanding of marine planktonic grazer-prey interactions.

Strain-specific algal responses to environmental stressors. Algae in a particular growth phase can ultimately alter the grazing pressure executed on them, through altered cellular nutrient content (e.g. in fatty acids) [30]. Previous studies found a strong correlation between phytoplankton fatty acid contents and herbivorous zooplankton production [32]. Carbon:Nitrogen ratio could also reflect alterations in relative lipid content [33].

The mucus produced in the stationary phase of diatom population growth can be used to distinguish different growth periods [31]. In addition, structures and amount of other compounds released by diatoms have been found to change in accordance with the 
growth period [34]. Eventually, a complex chemical composition was generated in the water surrounding phytoplankton cells, which spread the information of algal cell nutrient content, resulting food quality, and edibility versus toxiticity to copepods [35].

The diatom cell itself is able to respond to stimuli from the environment, such as fluid movement [36], osmotic pressure [11] and nutrient limitation [37]. Research indicates that diatoms detect and respond to physio-chemical changes in their environment using sophisticated perception systems based on changes in calcium concentration [11]. Besides detection of physical and chemical signals, diatoms can also perceive other friendly or hostile organisms in their surroundings [38]. Interestingly, marine diatoms can control population size of their zooplankton grazer by impairing their recruitment [39]. Work by Miralto and colleagues [14] showed that a diatom synthesized a special aldehyde molecule that can impair the hatching success of eggs [40], and the diatom's mitosis [41]. Therefore, such aldehydes may serve a signalling role by controlling the population size of diatoms in addition to providing a grazing defence mechanism, or a signal to terminate the outbreak of diatoms, which is quite different from the view that deems the recession of diatom reproduction is caused by nutritional deficiencies [42].

Through the assessment of genomic secrets of P. tricornutum [10], a series of transcriptomic research revealed unique transcriptomic signals generated by this successful diatom as a response to different individual environmental stressors - contaminants (copper, cadmium, etc), crude oil, ammonia and salinity changes [43]. Transcriptomic responses of $P$. tricornutum to nutrient-deprivation and lipid-accumulation indicated different carbonconcentrating mechanisms dependent upon exogenous DIC (dissolved inorganic carbon) levels [9], the importance of build-up precursors to the acetyl-CoA carboxylases in TAG (triacylglyceride) synthesis [9], and remodeling of intermediate metabolism (tricarboxylic acid and the urea cycles) [44]. The profile-based transcriptomic responses of $P$. tricornutum to phosphate availability suggested that the diatom-specific cyclins were predominantly expressed at the G1-to-S transition, hinting connection between cell division and environmental stimuli [45]. Genetic transposable elements suggested that small Heat Shock Proteins (sHSP) and Surcouf might be partly co-regulated and explained the over expression of Surcouf (retrotransposons) at high temperature [46]. As indicated above, transcriptomic level responses to many environmental stressors have been studied to-date in P. tricornutum, but these have not included the impacts of grazing activities, which hence will provide further understanding of $P$. tricornutum adaptation and responses to environmental stresses.

Grazing stress responses in the diatom P. tricornutum. Signal transmission between diatoms and their grazers is effective and complex. Yet, the body of research lacks studies focusing on the comprehensive responses of a diatom to a grazer. Therefore, we conducted an experimental study on the morphological, nutritional and transcriptomic responses of $P$. tricornutum to copepod grazing pressure to map regulatory components in the transcriptional rewiring of $P$. tricornutum metabolism under grazing stress.

\section{Materials and Methods}

\section{Phaedactylum tricornutum Strains and Culture Conditions}

Five strains of P. tricornutum (CCAP 1055/1, CCAP 632, CCAP 2557, CCAP 2558, CCAP 2560) were provided by Génomique, Environnementale et Evolutive Section 3 CNRS UMR8197, Institut de Biologie de l'ENS (IBENS). One strain of P. tricornutum (MACC B228) was provided by the Key Laboratory of Mariculture of Chinese Ministry of Education, Ocean University of China. The culture medium was prepared with sterile-filtered natural seawater from the North Sea (Minisart High-Flow $0.1 \mu \mathrm{m}$ syringe filter; Sartorius Stedim Biotech $\mathrm{GmbH}$, Goettingen, Germany), and enrichment nutrient solutions (macronutrients and micronutrients) based on a modified Provasoli medium $[47,48]$. P. tricornutum cells were grown at $18^{\circ} \mathrm{C}$ in a temperature-controlled room. The light intensity was constant at $100 \mu \mathrm{mol}$ photons $\cdot \mathrm{m}^{-2} \cdot \mathrm{s}^{-1}$ in a light:dark cycle of 12:12 h with 2 hours sunrise and 2 hours sunset phase simulations via irradiance profiles.

\section{KARGER}




\section{Cellular Physiology Cell Physiol Biochem 2018;46:1091-1111

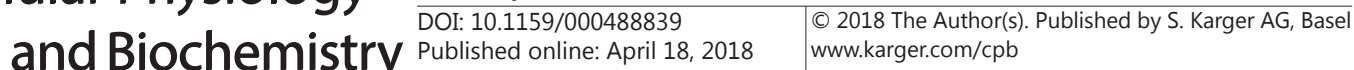

Li/Ismar: Responses of Phaeodactylum Tricornutum to Grazing Stress

\section{Experimental Set-up}

To generate grazing effect, over 2000 individuals of Acartia tonsa in $25 \mathrm{~L}$ seawater were fed with $1 \times 10^{7}$ P. tricornutum cells per day. Acartia was cultured in two nested buckets, with the bottom of the inner one replaced by a sieve with mesh size of $100 \mu \mathrm{m}$. Seawater was changed every day in the outer bucket with the faeces and eggs of Acartia removed. The culture medium of Acartia was filtered with a $0.1 \mu \mathrm{m}$ syringe filter into P. tricornutum grazing treatment replicates, while the same amount of sterile-filtered seawater (for culturing Acartia) with the same ratio of the pure medium (for culturing P. tricornutum) was added to the control groups.

Batch culture experiments were performed for each $P$. tricornutum strain under two treatments (control vs grazing). Each strain of $P$. tricornutum was cultured in $150 \mathrm{ml}$ culture medium. An extra $9 \mathrm{~L}$ culture of the two treatment groups repsectively was set up for strain CCAP 1055/1 in order to extract enough RNA for RNA sequencing (RNA-seq). Each treatment consisted of three replicates. The asymptote of the cell number changes was estimated from a previous study [49]. Once the early stationary phase was reached, the culture was harvested for further analysis.

Phaeodactylum in the grazing treatments thus only received Acartia-water, to enable a design that triggered responses to chemical cues of grazing pressure, without selection within the P. tricornutum strain by grazing selectivity.

\section{Morphological Analysis}

For morphological analysis, P. tricornutum cultures were sampled every two days for cell abundance counts and biovolume determination until the cultures reached an early stationary phase. Cell numbers were counted employing a Neubauer-Improved counting chamber (Paul Marienfeld Gmbh\&co.KG, LaudaKönigshofen, Germany). The biovolume was determined by measuring three dimensional size of 20 cells in each replicate and calculating volume from assumed geometric cell shape as described in [50]. All morphological assessment was conducted specifically by morphotype [51], distinguishing between fusiform, oval, and triradiate morphotypes of P. tricornutum cells.

\section{Nutritional Analysis}

For chemical analysis, $1 \mathrm{~mL}$ algal culture was harvested at the early stationary phase by filtration on pre-combusted Whatman GF/F filters (Whatman GmbH, Dassel, Germany). After filtration, samples for elemental analysis were immediately dried, and samples for FA analysis were frozen at $-80^{\circ} \mathrm{C}$. Measurements of POC (particulate organic carbon) and PON (particulate organic nitrogen) were conducted as described in Sharp [52] by gas-chromatography in an organic elemental analyzer (Thermo Flash 2000; Thermo Fisher Scientific Inc., Schwerte, Germany). FAs were measured as fatty acid methyl esters (FAMEs) using a gaschromatograph (Trace GC-Ultra; Thermo Fisher Scientific Inc.) according to the procedure detailed in Arndt and Sommer [53].

\section{RNA-sequencing}

For 9 L culture of strain CCAP 1055/1, cells from three biological replicates were collected at the exponential growth phase by centrifugation. The total RNA was extracted with RNeasy® Plant Mini Kit (QIAGEN, Hilden, Germany). RNA-Seq library protocol was used to construct P. tricornutum RNA-Seq libraries. For each of the six RNA samples, one single RNA-Seq library was constructed. Total RNA (5 $\mu \mathrm{g})$ was depleted of rRNA with the Ribo-Zero ${ }^{\mathrm{TM}}$ rRNA Removal Kits (Plant Leaf) (Epicentre® (an Illumina company), Madison, USA). Short fragments were purified and resolved with EB buffer (10 mM Tris- $\mathrm{Cl}, \mathrm{pH}$ 8.5) for end reparation and single nucleotide adenine addition. After that, short fragments were connected with adapters. After agarose gel electrophoresis, suitable fragments were selected for PCR amplification as templates. During the QC steps, Agilent 2100 Bioanaylzer and ABI StepOnePlus Real-Time PCR system were employed for quantification and qualification of the sample library. Then, a Trueseq 160 bp shortinsert library was constructed, and submitted to Illumina HiSeq2500 sequencing platform at BGI-Tech (HongKong) CO., LIMITED (Hong Kong, China).

For RNA-seq data analysis, raw reads were subjected to quality control (QC) for filtering. Reads, with adaptors, in which unknown bases contributed more than $10 \%$, and which were of low quality (defined by a percentage of low quality bases > $50 \%$ in a read; and with a sequencing quality no more than 10) were removed with Cutadapt [54]. Clean reads were mapped to Ensembl reference genome assembly 
GCA_000150955.2 with BWA method [55] then compared to GenBank GCF_000150955.2_ASM15095v2 GFF filtered models and genome files (http://www.ncbi.nlm.nih.gov/genome) [10,56] for further pathway analysis. Mapping reads were then submitted to NCBI GEO (GEO Accession No. GSE93297). All genes were annotated with KEGG Orthology, Go terms and Blast references. Genes and isoforms expression levels are quantified by Expectation-Maximization (EM) algorithm for paired-end (PE) and variable-length reads in RSEM software [57]. The significantly differentially expressed genes (DEGs) were determined with a modified method based on a poisson distribution.

The probability of gene A expressed equally between two samples can be calculated with:

$$
2 \sum_{i=0}^{i=y} p(i \mid x) \text { or } 2 \times\left(1-\sum_{i=0}^{i=y} p(i \mid x)\right)\left(\text { if } \sum_{i=0}^{i=y} p(i \mid x)>0.5\right), p(y \mid x)=\left(\frac{N_{2}}{N_{1}}\right)^{y} \frac{(x+y) !}{x ! y !\left(1+\frac{N_{2}}{N_{1}}\right)(x+y+1)},
$$

The total clean tag number of the sample 1 is $\mathrm{N} 1$, and total clean tag number of sample 2 is $\mathrm{N} 2$; gene $\mathrm{A}$ holds $\mathrm{x}$ tags in sample 1 and $\mathrm{y}$ tags in sample 2. The expression of DEGs was log2-transformed and visualized using the R heatmap.2 function in package qplots [58] with hierarchical cluster analysis. The Gene Ontology (GO) enrichment analysis was performed on Blast2Go [59]. KEGG pathway enrichment analysis was carried out with KOBAS 2.0 (KEGG Orthology Based Annotation System) [60].

\section{Statistics}

Cell abundance data was fitted with SSgompertz models to show the length of lag phase $\lambda$, the maximum growth rate $\mu$ and the maximum cell growth A. Mixed ANOVA with different covariance structure models was carried out on the cell numbers and biovolumes on each day in each treatment to determine the significance level of difference between treatment groups. Permutational MANOVA (Permutational Multivariate Analysis of Variance Using Distance Matrices) [61] was implemented on the overall fatty acid content per cell between the two groups of treatment (control and grazing group) for all strains. One way ANOVA was applied to test the differences of $\mathrm{C} / \mathrm{N}$ ratios between treatment groups. To test the differences in contents of each fatty acid between treatment groups, a Kruskal-Wallis rank sum test was carried out separately for all strains. Linear discriminant analysis (LDA) was practiced to depict comprehensive relationships between fatty acid contents, and biochemical responses to grazing for all tested $P$. tricornutum strains. All statistics were carried out in R [62], at a significance level of $\alpha=0.05$.

\section{Results}

Effects of Grazing on P. tricornutum Growth Rate and Biovolume

P. tricornutum response patterns to grazing stress showed morphological plasticity and morphotypespecific morphological effects. To further analyze such response patterns to grazing stress, we analyzed the impacts on diatom population growth rates in P. tricornutum. For all recorded morphotypes within strains, cell numbers differed significantly over time (Table 1), with significant interaction of time and treatment for some morphotypes within some strains. Overall, we recorded marked strain-specificity

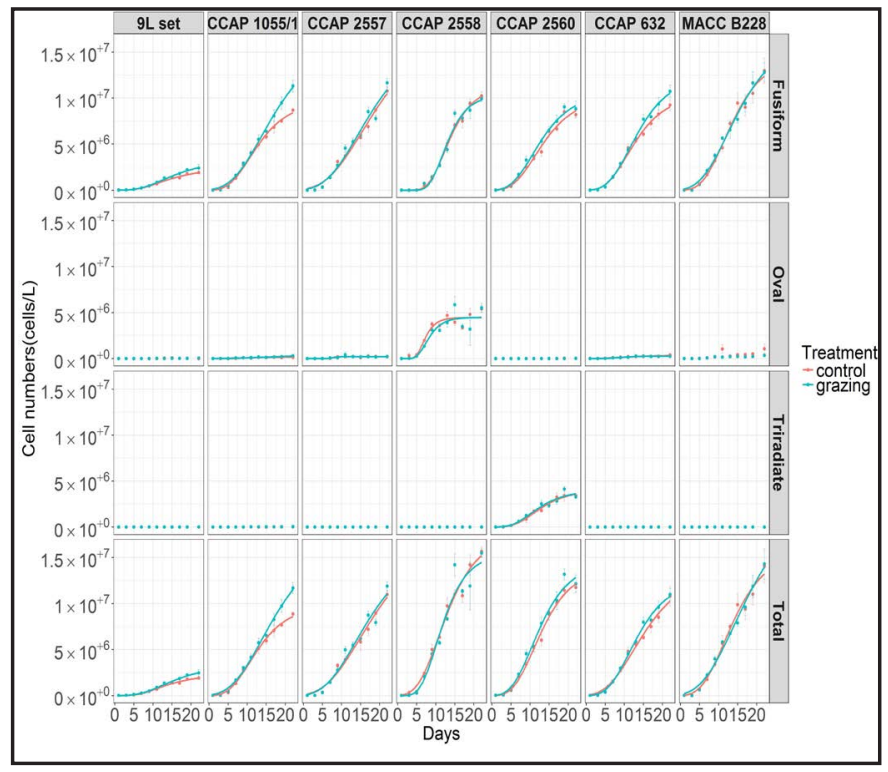

Fig. 1. Non-linear regressions of cell numbers of Phaeodactylum tricornutum; results from self-starting gompertz model showed different responses of six strains and three morphotypes of $\mathrm{P}$. tricornutum to the grazing effect. 9L set indicate the 9L set culture of CCAP1055/1 strain. The dots that could not be fitted by the SSgompertz showed low abundance of that morphotype. Error bar indicated the standard deviation.

\section{KARGER}




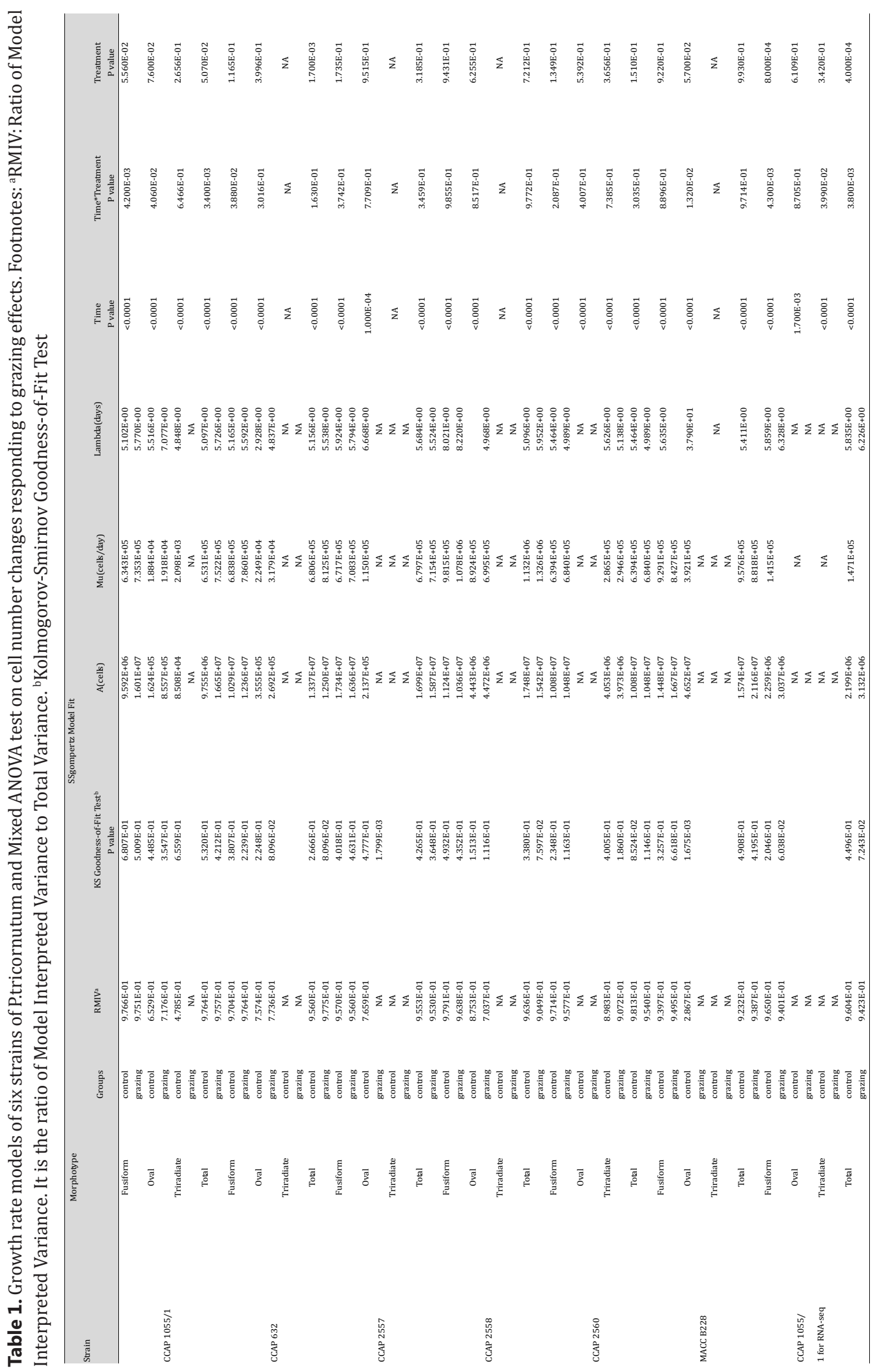


in responses of different morphotype abundances to simulated grazing pressure on $P$. tricornutum. These are listed in detail as follows:

Compared against the control group, fusiform and oval cell abundances under grazing stress showed a significant increase in fusiform cells and oval cells of strain CCAP 1055/1 of $150 \mathrm{~mL}$ sets (Fig. 1, Table 1). Oval cells in $9 \mathrm{~L}$ sets and triradiate cells in $150 \mathrm{~mL}$ sets of strain CCAP 1055/1 accounted for a small part of the overall morphotype numbers, and those cells within the grazing group did not show significant

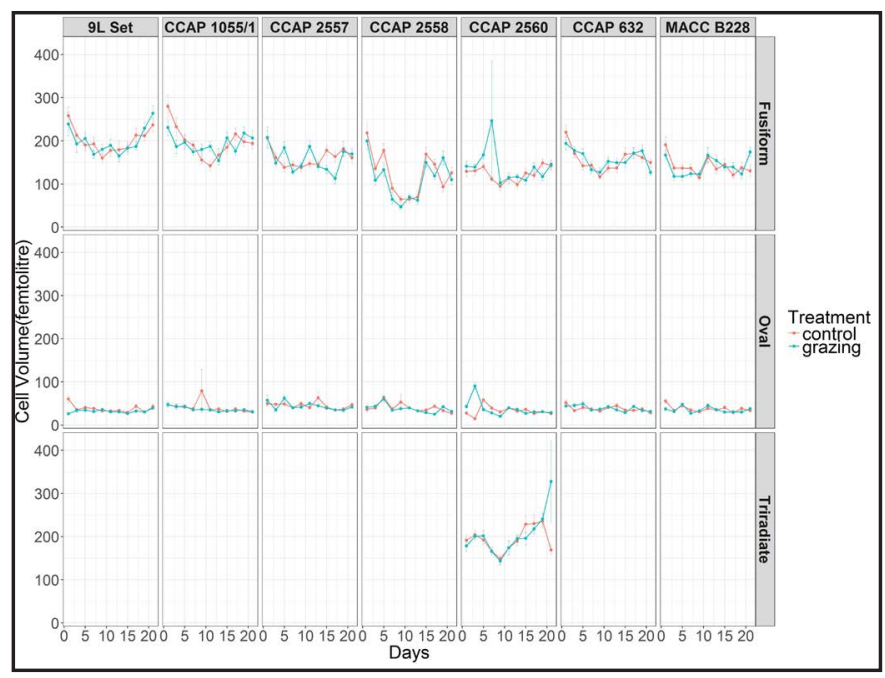

Fig. 2. Cellular biovolume response of six strains and three morphotypes of P. tricornutum to grazing effect. Error bar indicated the standard deviation. interaction between time and treatment compared to the control group (Table 1). Tri-radiate cells in $9 \mathrm{~L}$ sets of strain CCAP 1055/1 exhibited an increase in the grazing treatments compared against the control group, and the interaction between time and treatment was significant (Table 1). In total cell numbers, both sets of strain CCAP 1055/1 showed significant interactions between time and treatment (Table 1), and both sets displayed an increase in cell numbers in the grazing treatments compared against the respective control groups.

CCAP 632 cultures of the grazing treatments significantly increased compared against the control group over time on cell numbers of the fusiform morphotype (Fig. 1, Table 1). Oval and total cell numbers of CCAP 632 did not show any significantly different increase between two treatment groups (Fig. 1, Table 1), while tri-radiate cells were not traceable in the cultures.

CCAP 2557, CCAP 2558 and CCAP 2560 cultures did not display significant differences between control and grazing groups for any morphotype. In contrast to CCAP 1055/1 or CCAP 632 cultures, MACC B228 exhibited a unique pattern - abundances of oval cells in the control group increased significantly more over time compared to grazing treatments (Fig. 1, Table 1). However, in MACC B228, fusiform cells and total cell numbers did not respond to the simulated grazing pressure, with no significant difference between the two treatment groups found.

Cellular biovolume of the six P. tricornutum strains was measured to depict another morphological response parameter to grazing (Fig. 2). Mixed ANOVA expounded the strains behaved broadly complementarily in biovolume versus cell abundance responses, showing on average smaller cells at higher abundances, but no obvious morphotype-specific changes could be statistically corroborated.

As for morphotype-specific culture growth curves over time (depicting changes in cell abundances), biovolumes differed significantly along the within-subject time among all detectable morphotypes of $P$. tricornutum strains. However, considering interactions between time and treatment, for most strains the biovolumes of different morphotypes exhibited significant responses, which differed from those detected in cell abundance. Oval cells of 9 L cultures of CCAP 1055/1, fusiform cells of $150 \mathrm{~mL}$ cultures of CCAP 1055/1, oval cells of CCAP 632, fusiform cells of CCAP 2557, fusiform cells and oval cells of CCAP 2558, oval cells of CCAP 2560, and oval cells of MACC B228 displayed significant interactions between time and treatment with Greenhouse-Geisser corrected $F$ and $P$ values (Table 2). 
Effects of grazer presence on C: $N$ ratio and on fatty acid composition in P. tricornutum

One-way ANOVA indicated there was no significant difference between grazing groups and control groups in C:N ratio except CCAP $1055 / 1$ in $150 \mathrm{~mL}$ culture $[\mathrm{F}(1,4)=11.945, \mathrm{P}$ $=0.02591$ ] (Fig. 3).

Permutational MANOVA (Permutational Multivariate Analysis of Variance Using Distance Matrices) exhibited no consistent significant difference of fatty acid content per cell between the two treatment groups (control and grazing) among all strains (for all online suppl. material, see www.karger.com/ doi/ 10.1159/000488839, Suppl. Table 1). Yet, strain-specifically, contents of different fatty acids were significantly altered by simulated grazing pressure. As showed (see online suppl. material) in Suppl. Table 1, from Kruskal-Wallis rank sum tests between the two treatment groups (control and grazing), of polyunsaturated fatty acids (PUFAs), four strains - 9L sets and $150 \mathrm{~mL}$ sets of CCAP 1055/1, CCAP 632, CCAP 2558 and CCAP 2560 - each contained one, four, four, four and two significant changes of fatty acid content per cell respectively, while only $150 \mathrm{~mL}$ sets of CCAP 1055/1 exhibited significant change of total PUFA content per cell. With particular regard to ecologically important essential PUFAs - alpha-linolenic acid (ALA), eicosapentaenoic acid (EPA) and docosahexaenoic acid (DHA), $150 \mathrm{~mL}$ sets of CCAP 1055/1 showed significant changes in ALA content, and CCAP 2558 showed significant changes in EPA content. In saturated fatty acid (SFA), five strains -150 mL Sets of CCAP 1055/1, CCAP 632, CCAP 2558, CCAP 2560 and MACC B228 each exhibited significant responses in contents of four, three, six, two and two in fatty acids per cell, respectively. Regarding total SFA content per cell, $150 \mathrm{~mL}$ sets of CCAP 1055/1 and CCAP 2558 showed significant changes. Upon Total Fatty Acid (TFA), only CCAP 632 showed significant responses in both 18:1n9t and total TFA content per cell. Upon mono-unsaturated fatty acids (MUFA), three strains - CCAP 632, CCAP 2558 and MACC B228 - each showed significant responses in one, two and two fatty acid per cell separately, and only MACC B228 showed significant changes in total MUFA content per cell in response to simulated grazing. In CCAP 2557, no fatty acid showed a significant response to simulated grazing pressure (see online suppl. material, Suppl. Table 1, Fig. 4). There are four patterns in grazing-induced changes in diatom culture fatty acid contents, highlighted by significantly different FA contents per cell between treatment groups: 1 , most fatty acid contents in the grazing groups
Table 2. Mixed ANOVA results on the biovolume of six P. tricornutum strains responding to grazing effects

\begin{tabular}{lcccc}
\hline Strain & Morphotypes & Time & Time*Treatment & Treatment \\
\hline \multirow{2}{*}{ 9L Sets of CCAP 1055/1 } & Fusiform & $<0.0001$ & $6.095 \mathrm{E}-01$ & $8.917 \mathrm{E}-01$ \\
& Oval & $9.618 \mathrm{E}-04$ & $2.243 \mathrm{E}-03$ & $1.104 \mathrm{E}-04$ \\
& Fusiform & $<0.0001$ & $5.773 \mathrm{E}-03$ & $8.092 \mathrm{E}-01$ \\
$150 \mathrm{ml}$ Sets of CCAP 1055/1 & Oval & $3.419 \mathrm{E}-02$ & $3.562 \mathrm{E}-01$ & $9.895 \mathrm{E}-01$ \\
& Fusiform & $<0.0001$ & $3.580 \mathrm{E}-01$ & $6.890 \mathrm{E}-01$ \\
CCAP 632 & Oval & $<0.0001$ & $4.000 \mathrm{E}-03$ & $6.510 \mathrm{E}-01$ \\
& Fusiform & $<0.0001$ & $3.284 \mathrm{E}-04$ & $4.149 \mathrm{E}-01$ \\
CCAP 2557 & Oval & $3.000 \mathrm{E}-03$ & $1.650 \mathrm{E}-01$ & $2.560 \mathrm{E}-01$ \\
& Fusiform & $<0.0001$ & $3.000 \mathrm{E}-03$ & $4.900 \mathrm{E}-02$ \\
CCAP 2558 & Oval & $<0.0001$ & $2.075 \mathrm{E}-04$ & $4.822 \mathrm{E}-01$ \\
& Fusiform & $<0.0001$ & $1.580 \mathrm{E}-01$ & $1.470 \mathrm{E}-01$ \\
& Triridiate & $<0.0001$ & $6.500 \mathrm{E}-02$ & $9.752 \mathrm{E}-01$ \\
CCAP 2560 & Oval & $<0.0001$ & $<0.0001$ & $2.100 \mathrm{E}-02$ \\
& Fusiform & $<0.0001$ & $6.000 \mathrm{E}-02$ & $9.880 \mathrm{E}-01$ \\
MACC B228 & Oval & $<0.0001$ & $5.000 \mathrm{E}-03$ & $5.996 \mathrm{E}-02$ \\
& & & &
\end{tabular}

Fig. 3. Response of $\mathrm{C}: \mathrm{N}$ ratio in six strains of $\mathrm{P}$. tricornutum to grazing effects; error bars indicate $95 \%$ confidence interval $(97.5 \%$ above/below). 
decreased compared to those in the control groups. 2, the variances of the fatty acids contents converged in grazing groups compared against the control group. Ggrazing groups of all strains showed smaller variances than the control group among most fatty acids (Fig. 4). 3, among different fatty acid groups, the significant differences between the two treatment groups showed strain-specific patterns for both single fatty acid and total fatty acid amounts (see online suppl. material, Suppl. Table 1). 4, in strain CCAP 1055/1, contrasting responses of other tested $P$. tricornutum strains, most fatty acids (of which contents are obviously above average) had significantly higher cell contents in the control group than in the grazing group (see online suppl. material, Suppl. Table 1, Fig. 4). Linear discriminant analysis (LDA) on the combined data of the contents in each fatty acid, depicted pronounced and strainspecific responses to grazing. The proportions of explained variances were $72.92 \%$, $13.46 \%, 4.93 \% 3.63 \%, 2.06 \%$, $1.09 \%, 0.77 \%, 0.51 \%, 0.26 \%$, $0.14 \%, 0.11 \%, 0.08 \%, 0.04 \%$ for each discriminant. Coefficients of linear discriminants are provided (see online suppl. material) in Suppl. Table 2. The projections of each fatty acid proportion on first two linear discriminants (LDs) are shown in Fig. 5. LDA clearly

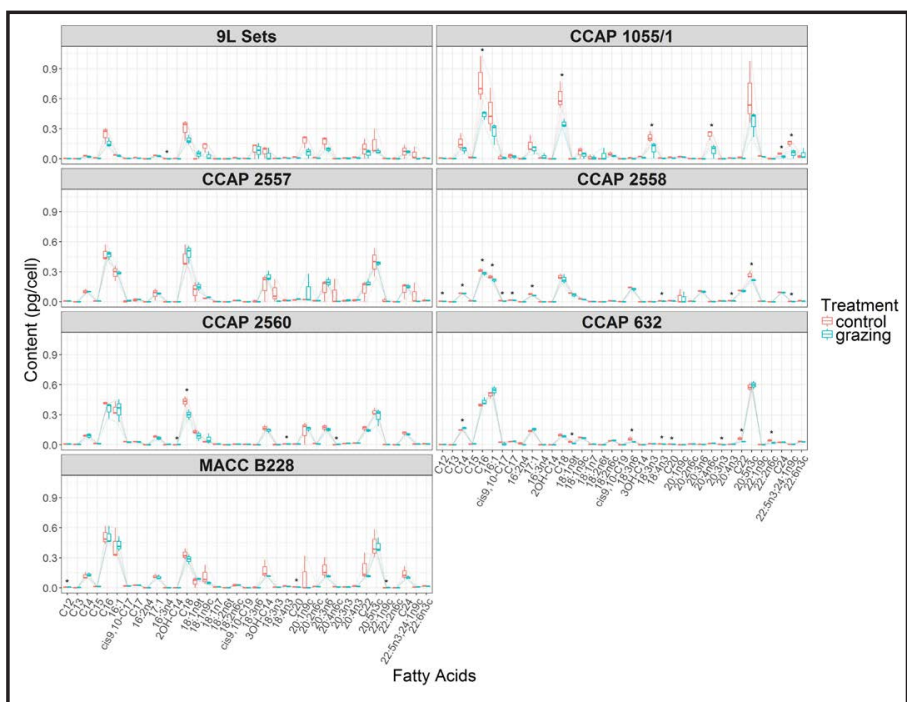

Fig. 4. Response of fatty acid content per cell under grazing effects; boxplot of each fatty acid content drawn with parallel coordinates, significant differences are indicated by asterisks.Fig.5 Linear discriminant analysis of the composition of fatty acids of six strains of P. tricornutum under grazing effects; folding lines exhibit the decision boundary of each treatment and each strain; polygons show K-means clustering result.

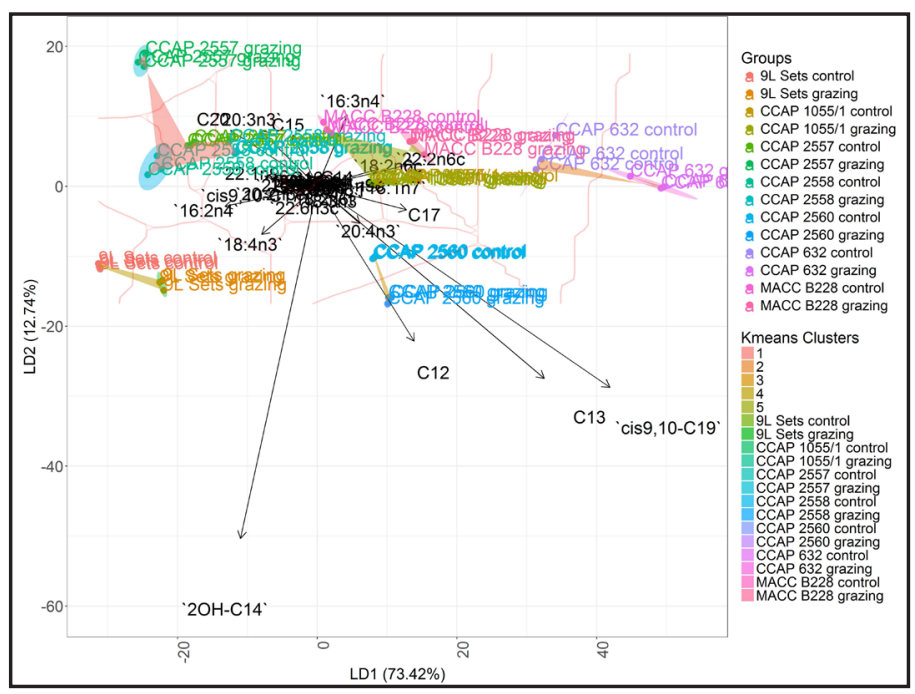

Fig. 5. Linear discriminant analysis of the composition of fatty acids of six strains of P. tricornutum under grazing effects; folding lines exhibit the decision boundary of each treatment and each strain; polygons show K-means clustering result. discriminated the treatment groups within the responses of each $P$. tricornutum strain, and the differences in FA composition between strains clearly, as shown by the decision boundaries and data ellipses (95\% confidence interval) (Fig. 5). For all strains, except $150 \mathrm{~mL}$ treatments of CCAP 1055/1, the first discriminant distinguished both strains and treatment groups significantly, and the second discriminant distinguished only strains significantly. These assessments are substantiated by two-way ANOVA on LDA results (see online suppl. material, Suppl. Table 3). The fatty acid compositions exhibited in 9L sets of CCAP 1055/1 and CCAP 632 had most different 


\section{Cellular Physiology Cell Physiol Biochem 2018;46:1091-1111

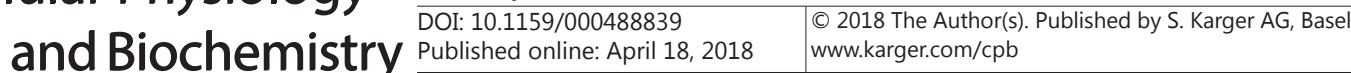

performance profiles, since they are at the two ends according to the main axis of variability. The treatment groups among strains exhibited five cluster groups $(1,9 \mathrm{~L}$ treatments of CCAP 1055/1; 2, 150 mL treatments of CCAP 1055/1 and MACC B228; 3, CCAP 2557 and 2558; 4, CCAP 2560; 5, CCAP 632) by K-means clustering based on the scores of each treatment observations (Fig. 5). Strains in each cluster were maximally discriminated based on treatment group, mainly by the different fatty acids (cluster 1:16:2n4>18:4n3> cis9, 10C17> 20:2n6c; group 2: 22:2n6c>16:4n3> 18:2n6c> 18:1n7> C14>17:1; group 3: C20> 20:3n3> 20:1n9c; group 4: cis9, 10C19> C13> C12> 20:4n3> 18:3n $>>18:$ 2n6t; group 5: 22:2n6c> 18:2n6c>18:1n7> C14>17:1) (Fig. 5).

\section{Transcriptomic response of $P$. tricornutum strain CCAP 1055/1 to copepod grazer presence \\ The mRNA of 9L cultures of strain} CCAP 1055/1 under three pairs of control and grazing treatments (three pairs of 1 vs 1 replicate) were extracted and submitted to Illumina HiSeq 2500 sequencing platform for paired-end sequencing. 171, 518, 402 total clean reads were obtained after trimming the adapters and filtering low-quality sequences. Clean reads were aligned to Ensembl reference genome assembly GCA_000150955.2 with BWA method. Mapping rates of each sample were: control 1, 67.65\%; control 2, 65.21\%; control 3, 82.1\%; grazing 1, 79.17\%; grazing 2, 61.69\%; grazing 3, 71.77\% (see online suppl. material, Suppl. Table 4).

The correlations between samples were calculated based on fragments per kilobase of exon per million mapped reads (FPKM). The results showed strong correlations within the same treatment group, but weak correlation between different treatment groups, grazing and control (Fig. 6). Differentially expressed genes (DEGs) between each pair of treatments (grazing and respective control) were calculated by a modified test based on Poisson distribution with BGI developed method. 1179, 1370 and 1198 significantly differential expressed genes were found in treatment pairs of control 1 vs grazing 1 ,

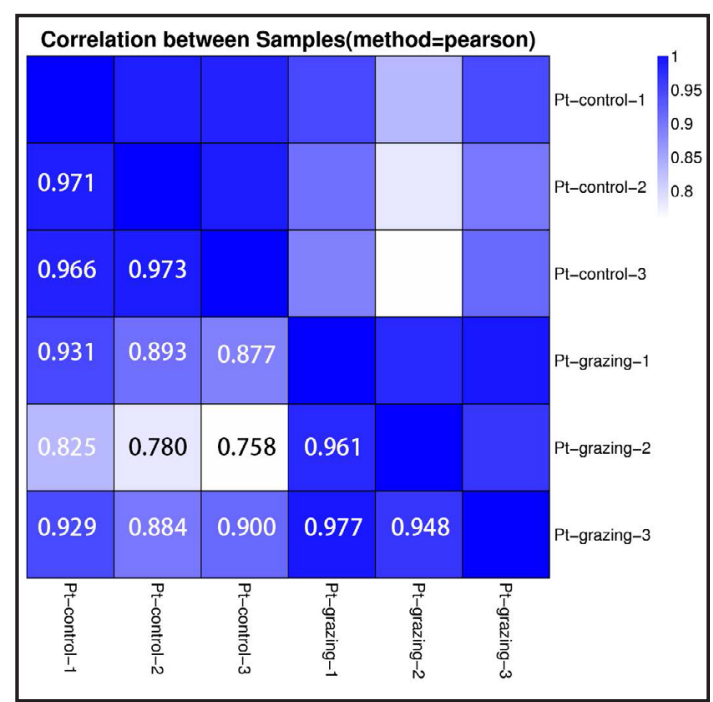

Fig. 6. Correlation between samples. Three biological replicates under two experiment conditions are set. The correlation value between each two samples based on FPKM result are calculated.

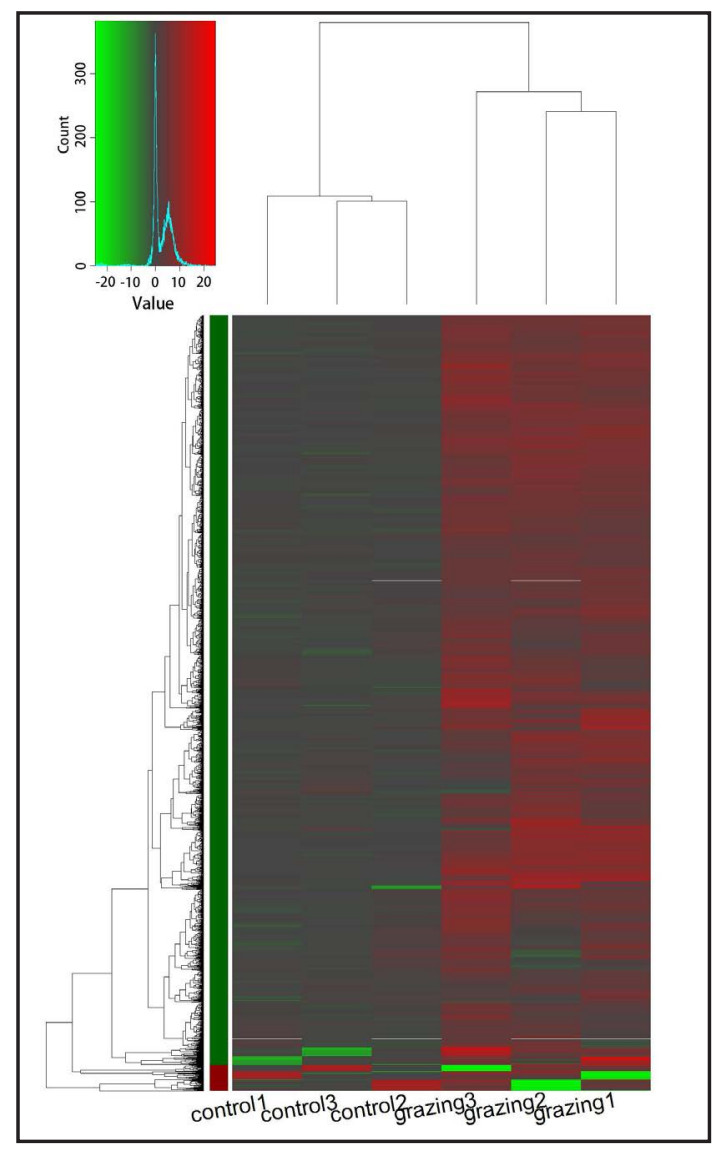

Fig. 7. Cluster analysis of heatmap of DEGs. Green bars represent the down-regulated genes. Red bars represent the up-regulated genes. The color depth represent the $\log 2$ ratio. 
Fig. 8. Circos map of enriched pathways of DEGs of 9L set of strain CCAP 1055/1 of P. tricornutum. The sections of circos map are abbreviations for the following pathways: 1, Alanine, aspartate and glutamate metabolism (Ala, asp, glu); 2, Amino sugar and nucleotide sugar metabolism (Ami, nuc); 3, Aminoacyl-tRNA biosynthesis (Ami-tRNA); 4, Arginine and proline metabolism (Arg,pro); 5, Arginine biosynthesis (Arg); 6, Ascorbate and aldarate metabolism (Asc, ald); 7, Biosynthesis of amino acids (Ami); 8, Carbon metabolism (Car); 9, Cell cycle - yeast (Cell cycle); 10, Collecting duct acid secretion (duct acid); 11, Fatty acid biosynthesis (Fatty acid); 12 , Fructose and mannose metabolism (Fru, man); 13, Glycine, serine and threonine metabolism (Gly, ser, thr); 14, Glycolysis or Gluconeogenesis (Gly, Glu); 15, Glyoxylate and dicarboxylate metabolism

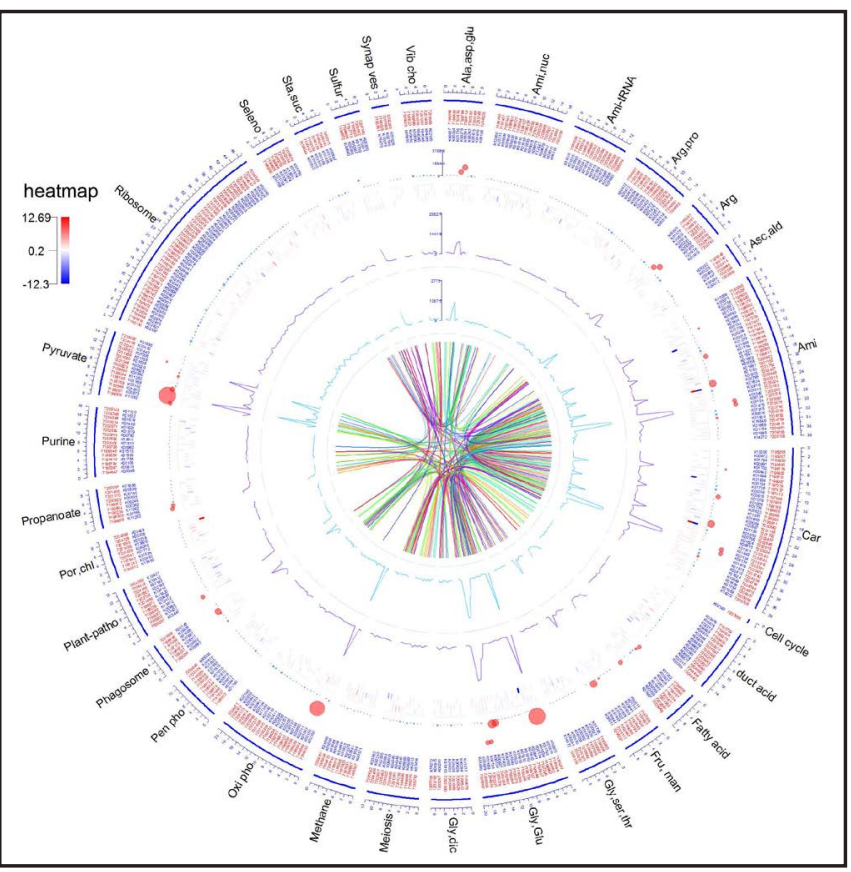
(Gly, dic); 16, Meiosis - yeast (Meiosis); 17, Methane metabolism (Mathane); 18, Oxidative phosphorylation (Oxi pho); 19, Pentose phosphate pathway (Pen pho); 20, Phagosome (Phagosome); 21, Plant-pathogen interaction (Plant-patho); 22, Porphyrin and chlorophyll metabolism (Por, chl); 23, Propanoate metabolism (Propanoate); 24, Purine metabolism (Purine); 25, Pyruvate metabolism (Pyruvate); 26, Ribosome (Ribosome); 27, Selenocompound metabolism (Seleno); 28, Starch and sucrose metabolism (Sta,suc); 29, Sulfur metabolism (Sulfur); 30, Synaptic vesicle cycle (Synap ves); 31, Vibrio cholerae infection (Vib cho). From outside to inside: Track 1 displays the gene IDs from GenBank; Track 2 displays corresponding KEGG Orthology names; Track 3 shows the standard deviation of FPKM values of each gene; Track 4 shows the heatmap of $\log 2$ ratio of each gene in 3 vs 3 (control vs grazing) experimental set-up; Track 5 shows the mean value of FPKM of the control group; Track 6 shows the mean value of FPKM from grazing group; the core part shows the linked KEGG Orthology by gene IDs in different pathways.

control 2 vs grazing 2, control 3 vs grazing 3, respectively (see online suppl. material, Suppl. Table 5). Cluster analyses results showed up- and down-regulation districted expression patterns among three paired treatment groups with the cut off value of 50 on the hierarchical cluster tree (Fig. 7). The gene ontology annotations of up- and down-regulated genes are shown (see online suppl. material) in Suppl. Fig. 1. Pathway enrichment analyses highlighted 31 enriched pathways with hypergeometric test $P$-value $<0.05$ and FDR (Benjamini and Hochberg method [63]) < 0.05 (Fig. 8, see online suppl. material, Suppl. Table 6).

In the plant-pathogen interaction pathway, seven nodes on the PAMP (pathogenassociated molecular pattern) -triggered immunity path were down-regulated which might trigger the reduced defense-related gene induction, reduce HR (hypersensitive response) and reduce cell wall reinforcement (Fig. 9a): two nodes on the fungal PAMP path involved in CDPK and Rboh-mediated ROS production; three as the bacterial flagellin perception and receptor kinase FLS2 and MEKK1; one as glycerol kinase involved in phytoalexin accumulation miRNA production; one as HSP90 leading to HR. Two nodes as $\mathrm{Ca}^{2+}$ mediated calmodulin and nitric-oxide synthase on NO mediated path to HR and cell wall reinforcement were up-regulated.

In the fatty acids biosynthesis pathway (Fig. 9b), 10 nodes functioning as 3-oxoacyl-[acylcarrier protein] reductase and acyl-[acyl-carrier-protein] desaturase were down-regulated on the paths to butyryl-, hexanoyl-, octanoyl-, decanoyl-, dodecanoyl-, tetradecanoyl-, hexadecanoyl-, hexadecenoyl-, octadecanoyl- and octadecenoyl- [acp]. Those paths further 


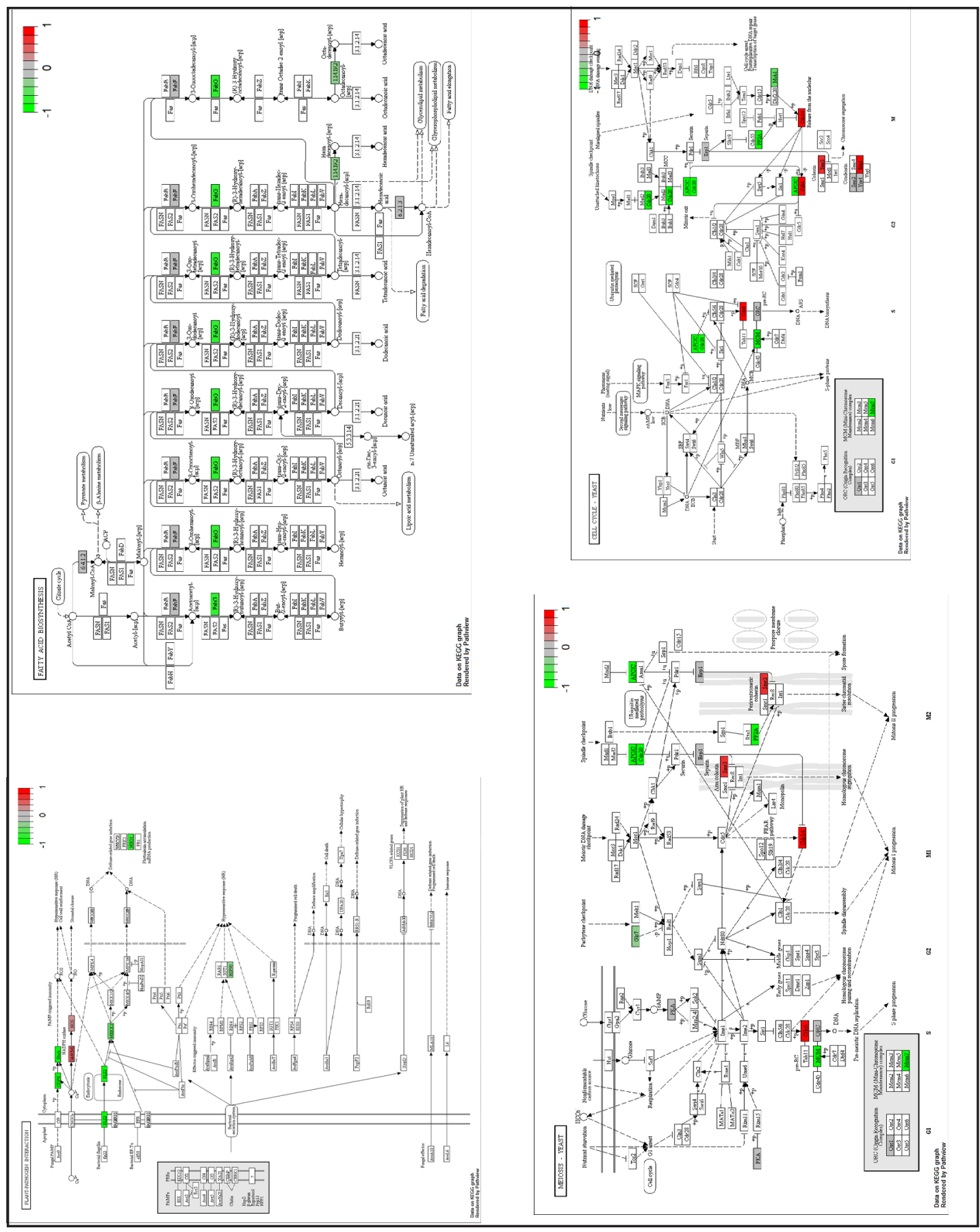

Fig. 9. Significantly differentially expressed genes in grazing stimulated culture of 9L set of strain CCAP 1055/1 of P. tricornutum-identified by KEGG Orthologies in Plant-Pathgen interaction pathway(A), Fatty acid biosynthesis pathway(B), Meiosis-yeast pathway (C) and Cell cycle pathway(D). Red: significantly increased expression; green: significantly decreased expression; grey: unchanged expression; empty squares, undetected in CCAP 1055/1. Fold-change values are normalized in the range between -1 and 1 .

extend to pathways of lipoic acid metabolism, fatty acid degradation, glycerolipid metabolism, glycerophospholipid metabolism and fatty acid elongation.

In the meiosis pathway (Fig. 9c), in the pre-replication complex, one node of Cdc6 was up-regulated to load more MCM proteins onto the complex. The other node of MCM7, which 
Li/Ismar: Responses of Phaeodactylum Tricornutum to Grazing Stress

functions as inhibiting genome replication in S-phase, was down-regulated. Regulation of these two nodes indicated enhanced DNA replication in the S-phase. In the cell cycle pathway (Fig. 9d), four down-regulated nodes (Glc7, APC/C, Cdc20) originally functioning as inhibitors, three up-regulated nodes (Smc3 and Cdc14), two down-regulated nodes (PP2A and Mob1) on paths to spindle disassembly, spore formation, sister chromatid resolution, and homologous chromosome segregation, indicated the boost of mitosis I and II progression and mitotic exit.

\section{Discussion}

In this study, we have quantified the effects of simulated grazing pressure on the growth and morphology of different $P$. tricornutum strains and have associated cell growth changes, and changes in cell nutritional content with changes in gene expression. The results show that $P$. tricornutum responded significantly both in growth rate and biochemical composition to grazing stress, and responses varied both in type and strength between different strains. Thus, grazing affected both growth and biochemical composition of $P$. tricornutum depending on strains with notable variability among them.

Strain-specific morphological and cell growth responses of P. tricornutum to grazer presence and related gene-regulation

P. tricornutum is considered unique in possessing the morphological plasticity to be able to grow without a rigid cell wall [64]. Previous research suggests that compared to oval cells, which are better adapted to stressful environments because of their capability to adhere and glide on surfaces, their higher sedimentation rates and rigid cell wall, tri-radiate and fusiform cells seem more adapted to stress-free planktonic environments [6,65]. Consistent with previous research, our result showed the fusiform and tri-radiate cells in the strains with one dominant morphotype (CCAP 1055/1, CCAP 632 and MACC B228) appeared prone to generate different growth responses to grazing stress (Fig.1, Table 1). In our experiment, the fusiform (CCAP 1055/1and CCAP 632) and tri-radiate cells (CCAP 1055/1) showed the significantly increased growth in the grazing treatment group compared to in the control group, while the oval cells showed non-significant differences in growth, indicating the different morphological types follow the same previously found pattern under stress.

Oval cells are considered to represent a key intermediate morphotype. This can convert either to fusiform or tri-radiate or to round cells depending on conditions [6]. This conversion-plasticity view was corroborated with our findings that the oval cells of strain MACC B228 increased significantly under stress, while the fusiform cell abundance remained similar (Table 1). This phenomenon is consistent with previous observations, in which [66] the author described the release of oval cells from fusiform cells as a consequence of nuclear transition between conjugated pairs of cells, thus confirming the potential sexual reproduction involved.

The fusiform morphotype classically was claimed the 'normal' form of this diatom $[67,68]$, and fusiform and triradiate morphologies possess an organic cell wall without silica $[69,70]$. Those characteristics grant a higher morphological plasticity and dominance compared with oval cells $[51,67]$. Our study observed that fusiform and triradiate cells within polymorphic strain (CCAP 2558 and CCAP 2560) had the capability of maintaining cell increase unaffected by simulated grazing pressure (Table 1), which hints at the possibility that morphological plasticity may act through buffering population growth from grazing impacts.

These complementary responses of biovolume (Table 2) against cell growth changes were further supported by the significant biovolume changes in our experiment. Previous grazing effect assessments operated on whole-habitat food web contexts [71], and ecotoxicological stress changes [72] showed the species-specific responses of phytoplankton at the experimental endpoint. Here, we provided a more comprehensive insight into time-lapsed responses to cues from the grazers on both, different morphotypes and different strains, of 
P. tricornutum. Among the morphotypes that exhibited significantly different interactions between time and treatment on biovolume, most showed complementary responses for biovolume and cell numbers to grazing, except strain-specific exceptions fusiform cells of $150 \mathrm{~mL}$ cultures of CCAP 1055/1 and oval cells of MACC B228. Investigated strain-9L sets of CCAP 1055/1- of P. tricornutum also showed transcriptomic responses to grazing cues, with significantly up- and down-regulated genes associated with pathways that are linked to the detected morphological and biochemical responses.

In the cell-cycle pathway (Fig. 9d) and in the meiosis pathway (Fig. 9c), Cdc6 has been proved functioning as G1 origin licensing crucial for proper S-phase DNA replication while depletion of Cdc6 could total block cells G1to S transition [73, 74]. Cdc6 binds to the replication origins first so that MCM proteins can bind [75]. Polyploid megakaryocytes show pronounced down regulation of MCM7 which goes through nonsense mediated decay (NMD) while its intronic miRNAs miR-106b-25 cluster is up-regulated [76]. Our results showed the up-regulated Cdc 6 with down-regulated MCM7 in the P. tricornutum cells in the grazing group indicate active replication of DNA response to the presence of grazing signals.

The Anaphase Promoting Complex/Cyclosome (APC/C), a large multi-subunit E3 ubiquitin ligase, triggers ubiquitin-mediated degredation of cell-cycle regulators through the addition of a polyubiquitin chain onto the target protein [77]. Cdc20 is a co-activator which APC/C depends on to bind destruction motifs in its substrates [78]. Phosphorylation of Cdc20 by cyclin A2-Cdk2 is required to repress APC/C-Cdc20 degradation activity in interphase to accumulate cyclins and hereby ensure efficient mitotic entry [79]. APC/C and Cdc20 were down-regulated in P. tricornutum in grazing treatments in this study, providing a window for accumulation of cyclins and thus facilitate mitotic entry. Structural Maintenance of Chromosome 3 protein (SMC3), as part of the cohesion complex that holds the sister chromatids together, participates in DNA-repair and recombination and microtubule-mediated intracellular transport. A previous study on human cells showed the increased cell growth rate and activation of rasrho/GTPase and cAMP pathways following SMC3 over expression [80]. Brn1 is a condensin subunit nuclear protein with a non-uniform distribution pattern, and its level is up-regulated at mitosis [81]. The SMC3 and Brn1which were up-regulated in P. tricornutum showed relevance in the pathway of mitosis leading to chromosome segregation, and in the context of increased growth rates, thus further providing SMC3 and Brn1 regulation profiles in a marine food web grazing scenario.

In budding yeast Saccharomyces cerevisiae, after anaphase, exit from mitosis requires the down-regulation of high mitotic cyclin-dependent kinase (Cdk) activity [82]. For this purpose, first, once anaphase begins, the sister chromatid-separating protease separase is activated and interacts with and down-regulates PP2A/Cdc55. Thus facilitating Cdkdependent Net1 phosphorylation [82]. Cdk and Polo-dependent phosphorylation of Net1 release active Cdc14-the Cdk counteracting phosphatase Cdc14 which is inhibited by Net1 in metaphase [83]. Cdc14 down-regulates Cdk by dephosphorylating Cdh- a second APC activatory subunit that sustains APC activity at low Cdk levels, and dephosphorylates the Cdk inhibitor Sic1[84]. Cdc14 pool is involved in several procedures - including those of making the metaphase-to-anaphase transition more abrupt, anaphase spindle stabilization, mitotic exit network (MEN) activation and mitotic exit - by reversing phosphorylation of cyclin-dependent kinase 1 (Cdk1) sites [85, 86]. Therefore, the down-regulation of PP2A, the up-regulation of Cdc14 and Cdh1 detected in this study may promote the mitotic exit and thus corroborate the higher growth rate of strain CCAP 1055/1 P. tricornutum in the grazing treatment group. Mob1 genes primarily participate in cell cycle progression and mitosis exit in eucaryotes. Previous research showed RNAi silenced Mob1-like gene (At5g45550) from Arabidopsis thaliana induced $a$ reduced radial expansion of the inflorescence stem, a reduced elongation zone of the primary root and a reduction in cell size [87]. These previous findings illuminate our observed significant changes of $P$. tricornutum biovolume with time and treatment interaction in the context of down-regulation of Mob1 in oval cells of 9L sets of CCAP 1055/1 in this study.

\section{KARGER}


Strain-specific chemical responses of P. tricornutum to grazer presence and related generegulation

The plant-animal interface in the food-web has been colloquially depicted as most dynamic and unique in its degree of heterogeneity [88]. Biochemical food quality, such as the phytoplankton cell quotas or intracellular storage, and internal nutrient reserves, was considered more important for the grazers. For instance, organisms with high quota flexibility can minimize the decrease in growth rate while species with rigid resource requirements (i.e., low quota flexibility) suffer decreases in growth rate [89]. In this study, the content change of each fatty acid among the strains suggested the heterogeneity of biochemical food quality would be a result of either a regulation from grazer's cue or an anti-grazing response from phytoplankton strains, since the diatom and its grazer had no physical contact in the experiment. Previous investigation of grazing impacts indicated that lipid depletion happened instantly after the cell disruption [90-92]. The grazing activity could drastically change the lipid and fatty acid content-especially the PUFAs which linked to the production of PUFA-derived polyunsaturated aldehydes (PUA) [90]. In addition, the PUAs were considered involved in the chemical defense of the algae in a way for example, decreased zooplankton egg-hatching success and offspring survival $[40,93]$. In our study, we could observe a common strategy adopted by P. tricornutum cells - reduction of total content and content variation in fatty acids to respond to grazing stress (Fig. 4). These responses of fatty acid in P. tricornutum provide a broader vision of the plant-animal trophic interface as the change of nutritional quality of phytoplankton diets could either be regulated by or actively booted against zooplanktonic herbivores chemical cues other than feeding-caused cell disruption. The significantly decreased total PUFA content in $150 \mathrm{~mL}$ sets of strain CCAP 1055/1 (Fig. 4, see online suppl. material, Suppl. Table 1) indicated the fatty acid depletion could also be induced by the chemical cue from feeding activity in vivo rather than by direct exposure of the fatty acid to the enzymes. In contrast to previous findings [90] when only PUFA depletion was detected after cell disruption, in our study, SFA, TFA and MUFA also exhibited significant decreases of both single fatty acids and total fatty acid content in the grazing group compared to the control group. This pattern disparity implies different mechanisms involved in fatty acid depletion, which were induced by chemical cues or cell disruption.

In the fatty acid biosynthesis pathway (Fig. 9b), fabG (3-oxoacyl-ACP reductase) catalyzes the NADPH-dependent reduction of beta-ketoacyl-ACP substrates to beta-hydroxyacyl-ACP products, in the elongation cycle of fatty acid biosynthesis [94]. In a previous study, Brassica napus was transformed with fabG in anti-sense orientation, leading to $90 \%$ reduction in fatty acid synthesized per plant [95]. In this study, the down-regulation of the fabG gene, EC 1.14.19.2 (stearoyl-[acyl-carrier-protein] 9-desaturase) revealed the reduction of content and content variation of the fatty acids per cell (Fig. 4) on a gene expression level and exhibited the nutritional regulation of $P$. tricornutum responding to the presence of grazing cues.

\section{Other transcriptomic responses of P. tricornutum strain CCAP 1055/1}

GLC7-encoding protein phosphatase-1 (PP1)-with a highly conserved amino acid sequence controls many processes in all eukaryotic cells, such as negative and positive effects on the production of mature, processed, cytoplasmic mRNA and snoRNA [96]. Downregulation of GLC7 is required for cell viability in a recessive gfa1 mutant while GFA1 encodes glutamine-fructose-6-phosphate amidotransferase which is essential for cell wall synthesis [97]. GLC7 was down-regulated in our study, combined with the down-regulation of CDPK and Rboh in the plant-pathogen interaction pathway, which further leads to the attenuation of cell wall reinforcement. The down-regulation of GLC7 represents its profile as being coregulated with cell wall attenuation in grazing responses in this study.

In the plant-pathogen interaction pathways (Fig. 9a), synthesis of reactive oxygen species (ROS) and $\mathrm{Ca}^{2+}$ concentration change triggers numerous signaling actions in the network plants deploy for appropriate defenses against herbivory [98]. Calcium-dependent 
protein kinases (CDPKs) which possess calmodulin-like calcium sensor and protein kinase effector domain take NADPH oxidases -which are integral membrane proteins encoded by the respiratory burst oxidase homolog (RBOH) gene family-as its phosphorylation target in pathogen-associated molecular patterns (PAMPs) [99]. RBOH proteins provide enzymatic systems for ROS production in plants. Previous quantitative phosphoproteomic analysis showed phosphorylation of RBOHD is critical in RBOHD-dependent ROS production [100]. The MAPK pathways act in parallel to CDPK involved pathway in PAMPs. In MAPK pathways, FLS2 is a leucine-rich repeat receptor kinase (LRR-RK) and a receptor for the bacterial PAMP flagellin or its active epitope -peptide flg22 [101, 102]. Flg22 treatment can inhibit Arabidopsis seedling development [103]. FLS2 activation further activates the MEKKMKK4/5-MPK3/6 and MEKK1-MKK1/2-MPK4 in MAP kinase pathways, and further WRKY transcription factors WRKY22/29 and WRKY25/33 before triggering transcription of defense-related genes [104]. A study on the phytohormone ethylene showed a mutation of the key ethylene-signaling protein EIN2 inhibited all FLS2-mediated responses, correlating with reduced FLS2 transcription and protein accumulation [105]. EIN2 activity controls the EIN3 and EIN3-like transcription factors, which controls FLS2 expression [105]. The nonhost resistance gene $\mathrm{NHO1}$-encoding a glycerol kinase-is required for multi-resistance-such as anti-bacteria, anti-fungal responses, and others [106, 107]. HSP90, normally functioning as a molecular chaperone participates disease-resistance in Arabidopsis. CDPK, Rboh, FLS2, MEKK1 genes-which lead to ROS production-and NHO1and HSP9O-which lead to disease resistance- are down-regulated in this study. This regulation pattern suggests a grazerdominated top-down regulation prevailing on a gene expression level, which will result in attenuation of hypersensitive response in $P$. tricornutum and hence reduce the chance of programmed cell death (PCD), which will provide a more abundant food source for the herbivore. Nitric oxide (NO) is also considered as a signal to defend plant from invaders $[108,109]$. Influx of extracellular $\mathrm{Ca}^{2+}$ can trigger the NO production through CNGCs (Cyclic Nucleotides-Gated ion Channel), CaM (calmodulin), nitric oxide synthase (NOS) [110]. In this study, CaM, NOS was up-regulated leading to enhanced HR and cell wall reinforcement [111]. Hence, the different regulation patterns - the up-regulation of CaM, NOS (the NO signaling pathway genes) versus the down-regulation of CDPK, Rboh, FLS2, MEKK1 (ROS pathway genes) and NHO1 and HSP9O - indicate a battle in gene expression between different signaling paths and between the benefits of the herbivore and the phytoplankton.

\section{Conclusion}

Our findings have shown strain-specific morphological, growth, and biochemical responses to grazer presence in the ubiquitous diatom $P$. tricornutum, and the studied strain CCAP 1055/1 illustrated that such responses can be mediated on a transcriptomic basis. Resulting grazing-induced effects may well alter prey edibility and prey availability to diatom grazers in natural plankton communities, and we argue that the extent of grazing pressure should be a biotic factor to be regularly considered when predicting algal growth in plankton communities under other environmental stressors, such as warming, ocean acidification, and/or hypoxia. The biochemical responses of $P$. tricornutum to grazer presence also show strain-specificity in direction of impact on biochemical nutrient quality, indicating grazerinduced increase in essential nutrient content in some strains, and a decrease in others. We suggest that the latter may represent strains which under natural conditions would be ahead in the predator-prey arms race with copepod grazers such as $A$. tonsa, while for the former scenario, copepod grazers would be able to manipulate cell biochemical responses in the grazers' favour. This raises the question, which environmental configurations select for grazers or algal prey respectively to be ahead in this predator-prey arms race. 


\section{Cellular Physiology Cell Physiol Biochem 2018;46:1091-1111

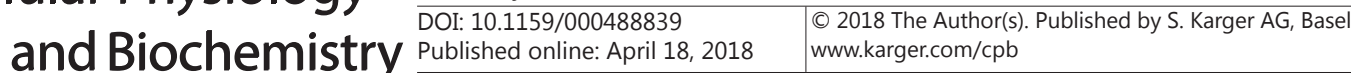

Li/Ismar: Responses of Phaeodactylum Tricornutum to Grazing Stress

\section{Acknowledgements}

We thank Thomas Hansen and Diana Gill for advice on laboratory procedures, and Ulrich Sommer for helpful comments on the manuscript. The study was supported by Colleges and Universities in Hebei Province Science and Technology Research Project (Grant No. QN20131082), Hebei Province Natural Science Foundation for Youths (Grant No. C2015202202) and National Natural Science Foundation of China (Grant No. 51474084). The study was conducted with support through a postdoctoral research stipend of the Chinese Scholarship Council (CSC) to S. Li, and from GEOMAR Helmholtz Center for Ocean Research Kiel, Germany.

\section{Disclosure Statement}

No conflict of interests.

\section{References}

1 Field CB, Behrenfeld MJ, Randerson JT, Falkowski P: Primary production of the biosphere: Integrating terrestrial and oceanic components. Science 1998;281:237-240.

2 Armbrust EV: The life of diatoms in the world's oceans. Nature 2009;459:185-192.

3 Boyce DG, Lewis MR, Worm B: Global phytoplankton decline over the past century. Nature 2010;466:591596.

4 Sommer U, Lewandowska A: Climate change and the phytoplankton spring bloom: Warming and overwintering zooplankton have similar effects on phytoplankton. Global Change Biol 2011;17:154-162.

5 Peter KH, Sommer U: Phytoplankton cell size: Intra- and interspecific effects of warming and grazing. PLoS ONE 2012; 7:e49632.

6 De Martino A, Bartual A, Willis A, Meichenin A, Villazán B, Maheswari U, Bowler C: Physiological and molecular evidence that environmental changes elicit morphological interconversion in the model diatom phaeodactylum tricornutum. Protist 2011;162:462-481.

7 Tesson B, Gaillard C, Martin-Jezequel V: Insights into the polymorphism of the diatom phaeodactylum tricornutum bohlin. Bot Mar 2009;52:104-116.

8 Chisti Y: Biodiesel from microalgae. Biotechnol Adv 2007;25:294-306.

-9 Valenzuela J, Mazurie A, Carlson RP, Gerlach R, Cooksey KE, Peyton BM, Fields MW: Potential role of multiple carbon fixation pathways during lipid accumulation in phaeodactylum tricornutum. Biotechnol Biofuels 2012;5:40.

10 Bowler C, Allen AE, Badger JH, Grimwood J, Jabbari K, Kuo A, Maheswari U, Martens C, Maumus F, Otillar RP, Rayko E, Salamov A, Vandepoele K, Beszteri B, Gruber A, Heijde M, Katinka M, Mock T, Valentin K, Verret F, Berges JA, Brownlee C, Cadoret J-P, Chiovitti A, Choi CJ, Coesel S, De Martino A, Detter JC, Durkin C, Falciatore A, Fournet J, Haruta M, Huysman MJJ, Jenkins BD, Jiroutova K, Jorgensen RE, Joubert Y, Kaplan A, Kroger N, Kroth PG, La Roche J, Lindquist E, Lommer M, Martin-Jezequel V, Lopez PJ, Lucas S, Mangogna M, McGinnis K, Medlin LK, Montsant A, Secq M-PO-L, Napoli C, Obornik M, Parker MS, Petit J-L, Porcel BM, Poulsen N, Robison M, Rychlewski L, Rynearson TA, Schmutz J, Shapiro H, Siaut M, Stanley M, Sussman MR, Taylor AR, Vardi A, von Dassow P, Vyverman W, Willis A, Wyrwicz LS, Rokhsar DS, Weissenbach J, Armbrust EV, Green BR, Van de Peer Y, Grigoriev IV: The phaeodactylum genome reveals the evolutionary history of diatom genomes. Nature 2008;456:239-244.

11 Falciatore A, d'Alcalà MR, Croot P, Bowler C: Perception of environmental signals by a marine diatom. Science 2000;288:2363-2366.

12 Muhseen ZT, Xiong Q, Chen Z, Ge F: Proteomics studies on stress responses in diatoms. Proteomics 2015;15:3943-3953.

13 Vardi A, Formiggini F, Casotti R, De Martino A, Ribalet F, Miralto A, Bowler C: A stress surveillance system based on calcium and nitric oxide in marine diatoms. PLoS Biol 2006;4:e60. 


\section{Cellular Physiology Cell Physiol Biochem 2018;46:1091-1111 and Biochemistry Publis.10.1159/000488839 $\begin{aligned} & \text { DO } 2018 \text { The Author(s). Published by S. Karger AG, Basel } \\ & \text { www.karger.com/cpb }\end{aligned}$

14 Miralto A, Barone G, Romano G, Poulet SA, Ianora A, Russo GL, Buttino I, Mazzarella G, Laabir M, Cabrini M, Giacobbe MG: The insidious effect of diatoms on copepod reproduction. Nature 1999;402:173-176.

15 Olson M, Lessard EJ, Wong CHJ, Bernhardt MJ: Copepod feeding selectivity on microplankton, including the toxigenic diatoms pseudo-nitzschia spp., in the coastal pacific northwest. Mar Ecol Prog Ser 2006;326:207220.

16 Wichard T, Poulet SA, Halsband-Lenk C, Albaina A, Harris R, Liu D, Pohnert G: Survey of the chemical defence potential of diatoms: Screening of fifty species for $\alpha, \beta, \gamma, \delta$-unsaturated aldehydes. J Chem Ecol 2005;31:949-958.

17 Harvey H: Note on selective feeding by calanus. J Mar Biol Assoc UK 1937;22:97-100.

18 Frost B: Effects of size and concentration of food particles on the feeding behavior of the marine planktonic copepod calanus pacificus. Limnol Oceanogr 1972:805-815.

19 Kleppel G: On the diets of calanoid copepods. Marine Ecology-Progress Series 1993;99:183-183.

20 Poulet S, Marsot P: Chemosensory grazing by marine calanoid copepods (arthropoda: Crustacea). Science 1978;200:1403-1405.

21 Huntley M, Barthel K-G, Star J: Particle rejection by calanus pacificus: Discrimination between similarly sized particles. Mar Biol 1983;74:151-160.

22 Breier CF, Buskey EJ: Effects of the red tide dinoflagellate, karenia brevis, on grazing and fecundity in the copepod acartia tonsa. J Plankton Res 2007;29:115-126.

-23 Waggett RJ, Tester PA, Place AR: Anti-grazing properties of the toxic dinoflagellate karlodinium veneficum during predator-prey interactions with the copepod acartia tonsa. Mar Ecol Prog Ser 2008;366:31-42.

24 Makino W, Ito K, Oshima Y, Urabe J: Effects of protoceratium reticulatum yessotoxin on feeding rates of acartia hudsonica: A bioassay using artificial particles coated with purified toxin. Harmful Algae 2008;7:639-645.

25 Selander E, Thor P, Toth G, Pavia H: Copepods induce paralytic shellfish toxin production in marine dinoflagellates. Proceedings of the Royal Society B: Biological Sciences 2006;273:1673-1680.

26 Huntley M, Sykes P, Rohan S, Marin V: Chemically-mediated rejection of dinoflagellate prey by the copepods calanus pacificus and paracalanus parvus: Mechanism, occurrence and significance. Mar Ecol Prog Ser 1986;28:105-120.

27 Hessen DO, Van Donk E: Morphological changes in scenedesmus induced by substances released from daphnia. ArchHydrobiol 1993;127:129-129.

28 Hansson L-A: Behavioural response in plants: Adjustment in algal recruitment induced by herbivores. Proceedings of the Royal Society of London Series B: Biological Sci 1996;263:1241-1244.

29 Van Donk E, Ianora A, Vos M: Induced defences in marine and freshwater phytoplankton: A review. Hydrobiologia 2011;668:3-19.

-30 Jónasdóttir S: Effects of food quality on the reproductive success of acartia tonsa and acartia hudsonica: Laboratory observations. Mar Biol 1994;121:67-81.

31 Malej A, Harris RP: Inhibition of copepod grazing by diatom exudates: A factor in the development of mucus aggregates? 1993.

-32 Giani A: Implications of phytoplankton chemical composition for zooplankton production: Experimental evidence. Oecologia 1991;87:409-416.

33 Mcconnaughey T, Mcroy CP: Food-web structure and the fractionation of carbon isotopes in the bering sea. Mar Biol 1979;53:257-262.

34 Barofsky A, Vidoudez C, Pohnert G: Metabolic profiling reveals growth stage variability in diatom exudates. Limnol Oceanogr Meth 2009;7:382-390.

35 Moore PA, Fields DM, Yen J: Physical constraints of chemoreception in foraging copepods. Limnol Oceanogr 1999:166-177.

36 Musielak MM, Karp-Boss L, Jumars PA, Fauci LJ: Nutrient transport and acquisition by diatom chains in a moving fluid. J Fluid Mechanics 2009;638:401-421.

37 Wolfe G: The chemical defense ecology of marine unicellular plankton: Constraints, mechanisms, and impacts. Biol Bulletin 2000;198:225-244.

-38 Falciatore A, Bowler C: Revealing the molecular secrets of marine diatoms. Annu Rev Plant Biol 2002;53:109-130. 


\section{Cellular Physiology Cell Physiol Biochem 2018;46:1091-1111 and Biochemistry \begin{tabular}{c|c} 
DOI: 10.1159/000488839 & $\begin{array}{l}\text { O 2018 The Author(s). Published by S. Karger AG, Basel } \\
\text { www.karger.com/cpb }\end{array}$
\end{tabular}

-39 Ianora A, Miralto A, Poulet SA, Carotenuto Y, Buttino I, Romano G, Casotti R, Pohnert G, Wichard T, ColucciD'Amato L, Terrazzano G, Smetacek V: Aldehyde suppression of copepod recruitment in blooms of a ubiquitous planktonic diatom. Nature 2004;429:403-407.

40 Miralto A, Barone G, Romano G, Poulet S, Ianora A, Russo G, Buttino I, Mazzarella G, Laabir M, Cabrini M: The insidious effect of diatoms on copepod reproduction. Nature 1999;402:173-176.

41 Casotti R, Mazza S, Ianora A, Miralto A: Growth and cell cycle progression in the diatom thalassiosira weissflogii is inhibited by the diatom aldehyde 2-trans-4-trans-decadienal: ASLO Aquatic Sciences 2001 Meeting, Special Session 2001:22:

-42 Brand LE, Sunda WG, Guillard RRL: Limitation of marine phytoplankton reproductive rates by zinc, manganese, and iron1. Limnol Oceanogr 1983;28:1182-1198.

43 Osborn HL, Hook SE: Using transcriptomic profiles in the diatom phaeodactylum tricornutum to identify and prioritize stressors. Aquat Toxicol 2013;138-139:12-25.

44 Levitan O, Dinamarca J, Zelzion E, Lun DS, Guerra LT, Kim MK, Kim J, Van Mooy BAS, Bhattacharya D, Falkowski PG: Remodeling of intermediate metabolism in the diatom phaeodactylum tricornutum under nitrogen stress. Proc Nat Acad Sci USA 2015;112:412-417.

-45 Huysman MJ, Martens C, Vandepoele K, Gillard J, Rayko E, Heijde M, Bowler C, Inzé D, Peer YVd, De Veylder L, Vyverman W: Genome-wide analysis of the diatom cell cycle unveils a novel type of cyclins involved in environmental signaling. Genom Biol 2010;11:1-19.

46 Egue F, Tastard E, Chénais B, Morant-Manceau A, Casse N, Caruso A: Expression of genetic transposable elements under thermal stress in the diatom phaeodactylum tricornutum: European Phycological Congress, 2015,

47 Ismar S, Hansen T, Sommer U: Effect of food concentration and type of diet on acartia survival and naupliar development. Mar Biol 2008;154:335-343.

48 Provasoli L: Growing marine seaweeds: Proc Int Seaweed Symp 1963:4:17.

49 Hayward J: Studies on the growth of phaeodaetylum tricornutum. Physiol Plant 1968;21:100-108.

50 Hillebrand H, Dürselen CD, Kirschtel D, Pollingher U, Zohary T: Biovolume calculation for pelagic and benthic microalgae. J Phycol 1999;35:403-424.

-51 Lewin JC, Lewin RA, Philpott DE: Observations on phaeodactylum tricornutum. J General Microbiol 1958;18:418-426.

52 Sharp JH: Improved analysis for "particulate" organic carbon and nitrogen from seawater. Limnol Oceanogr 1974;19:984-989.

53 Arndt C, Sommer U: Effect of algal species and concentration on development and fatty acid composition of two harpacticoid copepods, tisbe sp. And tachidius discipes, and a discussion about their suitability for marine fish larvae. Aquacult Nutr 2014;20:44-59.

54 Martin M: Cutadapt removes adapter sequences from high-throughput sequencing reads. 2011 2011;17

55 Li H, Durbin R: Fast and accurate short read alignment with burrows-wheeler transform. Bioinformatics 2009;25:1754-1760.

56 Trapnell C, Hendrickson DG, Sauvageau M, Goff L, Rinn JL, Pachter L: Differential analysis of gene regulation at transcript resolution with rna-seq. Nat Biotechnol 2013;31:46-53.

57 Li B, Dewey CN: Rsem: Accurate transcript quantification from rna-seq data with or without a reference genome. BMC Bioinformatics 2011;12:1-16.

58 Warnes GR, Bolker B, Bonebakker L, Gentleman R, Huber W, Liaw A, Lumley T, Maechler M, Magnusson A, Moeller S: Gplots: Various r programming tools for plotting data. R package version 2.12. 1, Available online at: h ttp://CRAN. R-project. org/package= gplots, 2013,

59 Conesa A, Götz S, García-Gómez JM, Terol J, Talón M, Robles M: Blast2go: A universal tool for annotation, visualization and analysis in functional genomics research. Bioinformatics 2005;21:3674-3676.

60 Xie C, Mao X, Huang J, Ding Y, Wu J, Dong S, Kong L, Gao G, Li C-Y, Wei L: Kobas 2.0: A web server for annotation and identification of enriched pathways and diseases. Nucleic Acids Res 2011;39:W316-W322.

61 Anderson MJ: A new method for non-parametric multivariate analysis of variance. Austral Ecol 2001;26:32-46.

62 R Core Team: R: A language and environment for statistical computing. 2016

63 Benjamini Y, Hochberg Y: Controlling the false discovery rate: A practical and powerful approach to multiple testing. Journal of the royal statistical society Series B (Methodological) 1995:289-300. 


\section{Cellular Physiology Cell Physiol Biochem 2018;46:1091-1111 and Biochemistry \begin{tabular}{c|c} 
DOI: 10.1159/000488839 & $\begin{array}{l}\text { O 2018 The Author(s). Published by S. Karger AG, Basel } \\
\text { www.karger.com/cpb }\end{array}$
\end{tabular}

64 Borowitzka MA, Volcani BE: The polymorphic diatom phaeodactylum tricornutum: Ultrastructure of its morphotypes1, 2. J Phycol 1978;14:10-21.

65 Tesson B: Insights into the polymorphism of the diatom phaeodactylum tricornutum bohlin. Bot Mar 2009;52:104-116.

66 Li S, Pan K, Zhu B, Zhang L: Nuclear transition between the conjunction cells of phaeodactylum tricornutum bohlin (bacillariophyta). J Ocean Univ China 2012;11:383-388.

67 Wilson DP: The triradiate and other forms of nitzschia closterium (ehrenberg) wm. Smith, forma minutissima of allen and nelson. J Mar Biol Assoc UK 1946;26:235-270.

68 Volcani BE: Cell wall formation in diatoms: Morphogenesis and biochemistry. 1981.

69 Borowitzka MA, Chiappino ML, Volcani BE: Ultrastructure of a chain-forming diatom phaeodactylum tricornutum1. J Phycol 1977;13:162-170.

70 De Martino A, Meichenin A, Shi J, Pan K, Bowler C: Genetic and phenotypic characterization of phaeodactylum tricornutum(bacillariophyceae) accessions. J Phycol 2007;43.

71 Miller R: Effects of a cyclopoid copepod (diacyclops thomasi) on phytoplankton and the microbial food web. Aquat Microb Ecol 1997;12:29-37.

72 Cloern JE, Dufford R: Phytoplankton community ecology: Principles applied in san francisco bay. Marine Ecology Progress 2005;285:11-28.

73 Lau E, Zhu C, Abraham RT, Jiang W: The functional role of cdc6 in s-g2/m in mammalian cells. EMBO Reports 2006;7:425.

74 Borlado LR, Mendez J: Cdc6: From DNA replication to cell cycle checkpoints and oncogenesis. Carcinogenesis 2008;29:237.

-75 Kearsey SE, Labib K: Mcm proteins: Evolution, properties, and role in DNA replication. Biochim Biophys Act 1998;1398:113.

76 Haldar S, Roy A, Banerjee S: Differential regulation of mcm7 and its intronic mirna cluster mir-106b-25 during megakaryopoiesis induced polyploidy. RNA Biology 2014;11:1137.

$\checkmark 77$ Peters J: The anaphase promoting complex/cyclosome: A machine designed to destroy. Nature Reviews Molecular Cell Biology 2006; 7:644.

78 Pines J: Cubism and the cell cycle: The many faces of the apc/c. Nat Rev Mol Cell Biol 2011;12:427-438.

79 Hein JB, Nilsson J: Interphase apc/c-cdc20 inhibition by cyclin a2-cdk2 ensures efficient mitotic entry. Nature Comm 2016;7

80 Ghiselli G, Liu C: Global gene expression profiling of cells overexpressing smc3. MolCancer 2005;4:34.

81 Ouspenski, II, Cabello OA, Brinkley BR: Chromosome condensation factor brn1p is required for chromatid separation in mitosis. Mol Biol Cell 2000;11:1305-1313.

82 Queralt E, Lehane C, Novak B, Uhlmann F: Downregulation of pp2acdc55 phosphatase by separase initiates mitotic exit in budding yeast. Cell 2006;125:719-732.

83 Visintin R, Hwang ES, Amon A: Cfi1 prevents premature exit from mitosis by anchoring cdc14 phosphatase in the nucleolus. Nature 1999;398:818-823.

-84 Visintin R, Craig KL, Hwang ES, Prinz S, Tyers M, Amon A: The phosphatase cdc14 triggers mitotic exit by reversal of cdk-dependent phosphorylation. Mol Cell 1998;2:709-718.

85 Mocciaro A, Schiebel E: Cdc14: A highly conserved family of phosphatases with non-conserved functions? J Cell Sci 2010;123:2867-2876.

86 Higuchi T, Uhlmann F: Stabilization of microtubule dynamics at anaphase onset promotes chromosome segregation. Nature 2005;433:171-176.

87 Galla G, Zenoni S, Marconi G, Marino G, Botton A, Pinosa F, Citterio S, Ruperti B, Palme K, Albertini E: Sporophytic and gametophytic functions of the cell cycle-associated mob1 gene in arabidopsis thaliana 1. Gene 2011;484:1-12.

88 Perhar G, Arhonditsis GB, Brett MT: Modelling the role of highly unsaturated fatty acids in planktonic food web processes: Sensitivity analysis and examination of contemporary hypotheses. Ecological Informatics 2013;13:77-98.

89 Goldman JC, McCarthy JJ: Steady state growth and ammonium uptake of a fast-growing marine diatom 1. Limnol Oceanogr 1978;23:695-703.

90 Wichard T, Gerecht A, Boersma M, Poulet SA, Wiltshire K, Pohnert G: Lipid and fatty acid composition of diatoms revisited: Rapid wound-activated change of food quality parameters influences herbivorous copepod reproductive success. ChemBioChem 2007;8:1146-1153. 


\section{Cellular Physiology Cell Physiol Biochem 2018;46:1091-1111 and Biochemistry \begin{tabular}{l|l} 
DOI: 10.1159/000488839 & Published 2018 The Author(s). Published by S. Karger AG, Basel \\
www.karger.com/cpb
\end{tabular}

-91 Pohnert G: Wound-activated chemical defense in unicellular planktonic algae. Angewandte Chemie Int Ed2000;39:4352-4354.

92 Wichard T, Poulet SA, Halsband-Lenk C, Albaina A, Harris R, Liu D, Pohnert G: Survey of the chemical defence potential of diatoms: Screening of fifty one species for alpha,beta,gamma,delta-unsaturated aldehydes. J Chem Ecol 2005;31:949-958.

93 Pohnert G: Diatom/copepod interactions in plankton: The indirect chemical defense of unicellular algae. ChemBioChem 2005;6:946-959.

-94 Heath RJ, Rock CO: Inhibition of beta-ketoacyl-acyl carrier protein synthase iii (fabh) by acyl-acyl carrier protein in escherichia coli. J Biol Chem 1996;271:10996-11000.

-95 O'Hara P, Slabas AR, Fawcett T: Antisense expression of 3-oxoacyl-acp reductase affects whole plant productivity and causes collateral changes in activity of fatty acid synthase components. Plant Cell Physiol 2007;48:736-744.

-96 Cannon JF: Function of protein phosphatase-1, glc7, in saccharomyces cerevisiae. Adv Appl Microbiol 2010:27-59.

-97 Zheng J, Khalil M, Cannon JF: Glc7p protein phosphatase inhibits expression of glutamine-fructose-6phosphate transaminase from gfa1. J Biol Chem 2000;275:18070-18078.

-98 Wu J, Baldwin IT: New insights into plant responses to the attack from insect herbivores. Annu Rev Genet 2010;44:1-24.

99 Romeis T, Piedras P, Jones JDG: Resistance gene-dependent activation of a calcium-dependent protein kinase in the plant defense response. Plant Cell 2000;12:803-815.

100 Benschop JJ, Mohammed S, Oflaherty M, Heck AJR, Slijper M, Menke FLH: Quantitative phosphoproteomics of early elicitor signaling in arabidopsis. Mol Cell Proteom2007;6:1198-1214.

101 Zipfel C: Early molecular events in pamp-triggered immunity. Curr Opin Plant Biol 2009;12:414-420.

102 Boller T, Felix G: A renaissance of elicitors: Perception of microbe-associated molecular patterns and danger signals by pattern-recognition receptors. Annu Rev Plant Biol 2009;60:379-406.

103 Gomezgomez L, Felix G, Boller T: A single locus determines sensitivity to bacterial flagellin in arabidopsis thaliana. Plant J 1999;18:277-284.

104 Nicaise V, Roux M, Zipfel C: Recent advances in pamp-triggered immunity against bacteria: Pattern recognition receptors watch over and raise the alarm. Plant Physiol 2009;150:1638-1647.

105 Boutrot F, Segonzac C, Chang KN, Qiao H, Ecker JR, Zipfel C, Rathjen JP: Direct transcriptional control of the arabidopsis immune receptor fls2 by the ethylene-dependent transcription factors ein 3 and eil1. Proc Nat Acad Sci USA 2010;107:14502-14507.

106 Li Kang JL, Tiehan Zhao, Fangming Xiao, Xiaoyan Tang, Roger Thilmony, ShengYang He, Jian-Min Zhou: Interplay of the arabidopsis nonhost resistance gene nho1 with bacterial virulence. Proc Nat Acad Sci 2003;100:3519-3524.

107 Lu M, Tang X, Zhou J: Arabidopsis nho1 is required for general resistance against pseudomonas bacteria. Plant Cell 2001;13:437-447.

108 Delledonne M, Xia Y, Dixon RA, Lamb CJ: Nitric oxide functions as a signal in plant disease resistance. Nature 1998;394:585-588.

109 Durner J, Wendehenne D, Klessig DF: Defense gene induction in tobacco by nitric oxide, cyclic gmp, and cyclic adp-ribose. Proc Nat Acad Sci USA 1998;95:10328-10333.

110 Ma W, Berkowitz GA: Ca2+ conduction by plant cyclic nucleotide gated channels and associated signaling components in pathogen defense signal transduction cascades. New Phytol 2011;190:566-572.

111 Noorbakhsh Z, Taheri P: Nitric oxide: A signaling molecule which activates cell wall-associated defense of tomato against rhizoctonia solani. Eur J Plant Pathol 2015;144:551-568. 